\title{
Keeping it Clean: Plan Your Cleaning ${ }^{1}$
}

Mary N. Harrison ${ }^{2}$

\section{Clean as You Go}

The clean as you go plan makes it easy to have a clean and orderly home.

- Develop a basic cleaning schedule. Keep it simple and stick to it.

- Plan projects that you can complete in the time that you have.

- Involve your family. All members working together help to make it easy to keep your home in good condition.

- Keep all cleaning supplies and equipment in one place that way they are easy to find and move from job to job.

\section{Tasks to do Immediately}

Some tasks should be done immediately:

- Hang up clothing and coats as soon as you take them off. Put dirty clothes in the hamper.

- Clean dishes right after you eat.
- Make your bed as soon as you get up.

- Put things back in place after you use them.

\section{Tasks to do Less Often}

Examples of tasks that you do less often:

- Change the bed sheets each week.

- Do the family laundry weekly or more often if needed.

- Wash windows each spring (or as needed).

- Change the filter in your furnace/air conditioner.

Household tasks are easy to handle if you follow a schedule, but they become difficult if neglected.

1. This document is FCS5232-02, one of a series of the Family Youth and Community Sciences Department, Florida Cooperative Extension Service, Institute of Food and Agricultural Sciences, University of Florida. Original publication date June 2002. Revised December 2005. Visit the EDIS Web Site at http://edis.ifas.ufl.edu.

2. Mary N. Harrison, professor, Department of Family, Youth and Community Sciences, Cooperative Extension Service, Institute of Food and Agricultural Sciences, University of Florida, Gainesville, 32611

The Institute of Food and Agricultural Sciences (IFAS) is an Equal Opportunity Institution authorized to provide research, educational information and other services only to individuals and institutions that function with non-discrimination with respect to race, creed, color, religion, age, disability, sex, sexual orientation, marital status, national origin, political opinions or affiliations. U.S. Department of Agriculture, Cooperative Extension Service, University of Florida, IFAS, Florida A. \& M. University Cooperative Extension Program, and Boards of County Commissioners Cooperating. Larry Arrington, Dean 